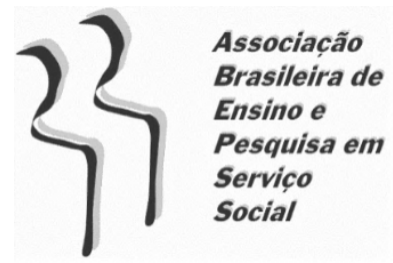

\title{
NOTA DA ABEPSS AOS ESTUDANTES DE EAD JUNHO DE 2011
}

ABEPSS' note to distance education students

A Associação Brasileira de Ensino e Pesquisa em Serviço Social, nos seus 65 anos, vem construindo seu reconhecimento como entidade acadêmico-científica e política, na área do Serviço Social, em defesa e garantia de um ensino público, gratuito, laico, de qualidade e socialmente referenciado na direção dos valores e princípios do projeto ético-político profissional.

Nesta perspectiva, desde muito tempo, vem denunciando a precariedade do ensino e as baixas condições e relações de trabalho docente no Brasil. Precariedade essa que perpassa todo o ciclo da educação em nosso país - do Ensino Fundamental aos Programas de Pós-Graduação, assumindo diversos formatos.

No que se refere ao Ensino Superior, tal precariedade se expressa nas instituições públicas e privadas, nas modalidades presencial e a distância.

Várias denúncias chegam até nós, por parte do corpo discente e docente dessas Instituições de Ensino Superior (IES). Um bom exemplo disso é o pedido de apoio ao movimento estudantil e de professores de universidades públicas federais que denunciam as precárias condições de trabalho nestas universidades e suas 
consequências para o processo de formação profissional do assistente social.

Igualmente, docentes e discentes de alguns cursos privados, preocupados com a formação, pedem nossa intervenção junto à sua unidade, no sentido de fortalecer a luta pela qualificação profissional e condições de trabalho.

Sabemos que essa Política Nacional de Educação voltada, indiscutivelmente, para ampliação de mercado tem privilegiado interesses estranhos à lógica da formação de quadros intelectuais aptos a responderem de maneira qualificada às questões estruturais e complexas que tecem a sociedade brasileira. Na lógica mercadológica, quanto mais rápido, ligeiro e barato o ensino, mais ele atenderá aos objetivos de formar trabalhadores para se adaptarem às condições e relações de trabalho precarizadas, competitivas e individualistas.

Tais interesses não se preocupam com a qualidade do ensino e sim com quantidade, ou melhor, qualidade somente para alguns privilegiados, fortalecendo a DISTINÇÃO entre universidades de ensino - instrumentos de profissionalização aligeirada, sem ambiente de pesquisa - e universidades de pesquisa - instituições pautadas pelo tripé ensino, pesquisa e extensão, como condição para uma formação teórico-crítica indispensável.

Entendemos que os cursos superiores devam formar profissionais qualificados nas mais diversas especialidades - muitos deles, interferindo, diretamente na vida da população, como é o caso do Serviço Social. Dessa forma, qual é o perfil do profissional que responde às necessidades da sociedade brasileira hoje? É este o parâmetro para pensarmos que profissional queremos formar. Mas para atender a que interesses desta sociedade? A ABEPSS, 


\section{tempordlis}

coerente com o projeto ético-político da profissão, defende um profissional com competência teórico-metodológica, ético-política e técnico-operativa. Um profissional crítico às investidas do grande capital, na direção de transformar a educação em mercadoria, capaz de privilegiar a defesa dos direitos sociais e humanos, a ampliação da cidadania e a consolidação da democracia. Ou seja, formar intelectuais que possuam responsabilidades sociais sobre os aspectos da vida social, que atendam necessidades das classes trabalhadoras e, além disso, sejam capazes de propor projetos de intervenção profissional que possam ir além das demandas do mercado (ABEPSS, 1996).

Nesta direção, defendemos que todos os estudantes merecem uma formação qualificada, em consonância com os princípios e valores do Projeto ético-político profissional hegemônico.

É nesse sentido que foi lançada a campanha Educação não é Fastfood. Consideramos que todos que querem e precisam se profissionalizar tenham oportunidades iguais, que não precisem pagar pela educação que desejam e que esta seja de qualidade para todos. Nossa luta consiste em ampliar e fortalecer os espaços de formação com condições de ensino de qualidade para todos aqueles que escolherem essa profissão como desafio.

O papel da ABEPSS, CFESS, ENESSO e ANDES nessa Campanha é o de evidenciar a importância da formação de qualidade, resguardando a devida atenção aos princípios fundamentais que sustentam o Serviço Social para um exercício profissional compatível com os desafios de atuar nas diferentes, múltiplas e contraditórias expressões da questão social na realidade brasileira. Para isso, cabe desenvolver durante a formação a capacidade de análise do movimento histórico da sociedade brasileira, apreendendo as particularidades do desenvolvimento do 


\section{tempordils}

capitalismo no país, considerando as particularidades regionais. Esse movimento pressupõe a inserção dos sujeitos nesta realidade local, com aproximação teórico-prática nas diversas disciplinas, articulando ensino, pesquisa e extensão (atividades eminentemente orientadas e realizadas presencialmente) de outros princípios presentes nas Diretrizes Curriculares.

Nesta direção, contamos com a ampla participação de todos/as nas denúncias contra a precarização do ensino e a maneira irresponsável que algumas instituições têm dispensado à formação de profissionais, num quadro de exploração dos jovens trabalhadores.

Na busca por tal concepção de formação, nossa luta é pela não discriminação da educação, é pelo acesso de todos à educação pública, gratuita e de QUALIDADE.

Essa deve ser a luta de todos nós!

\section{Associação Brasileira de Ensino e Pesquisa em Serviço Social Gestão 2011-2012}

